\title{
ENGLISH TEACHERS' PERCEPTIONS ABOUT THEIR TEACHING: USING ACTIVITY THEORY TO IDENTIFY CONTRADICTIONS
}

\author{
Ardi Marwan \\ Politeknik Negeri Pontianak, Indonesia
}

\begin{abstract}
This paper highlights the findings of a study which was undertaken at a vocational higher institution in Indonesia. The aim of the study was to explore English teachers' perceptions about their English language teaching (ELT) in this institution. Activity theory (AT) was employed as the framework for guiding the study owing to the fact that its focus was on the identification of contradictions occurring in the activity system. From AT analysis, several contradictions could be located within the context of ELT in this institution. Recommendations for the improvement of ELT in this particular institution were also provided.
\end{abstract}

Key words: activity theory, English language teaching, contradictions

The research reported in this paper was carried out with four English teachers working full time at a vocational higher institution in Indonesia. It aims to explore teachers' perceptions regarding their English teaching in this institution and Activity Theory (AT) was adopted as the framework of the study.

A search of current literature suggests that most studies involving AT as the framework (for analysis) were conducted mostly within the area of information and communication technology (ICT) integration (Demiraslan \& Usluel, 2008; Lim \& Hang, 2003; P. Murphy, 2007; Robertson, 2008) and very few focused on the context of English language teaching and learning. In fact, only one study could be located within this later area (Nelson, 2002). Thus, the current research is of particularly important because it addresses the area where there is only little information available.

Activity Theory (AT) is thought to be "the best kept secret in academia" (Engestrom, 1993) because its popularity for use in the field of education, particularly in Western context, has just recently emerged (Demiraslan \& Usluel, 
2008 and Robertson, 2008). AT can be effectively used as a lens to understand the important issues related to a certain matter (Murphy \& RodruguezManzanares, 2008). In essence, AT can be applied to various fields including, for example, medicine (Engestrom, 1993) and education (Lim \& Hang, 2003) provided that it can be consistently used according to its principle.

Engestrom (2001) points out that there are six elements incorporated in AT, namely subject, object, tool, community, rules and division of labor (see Figure 1). It is these elements which distinguish AT from other types of framework or theory.

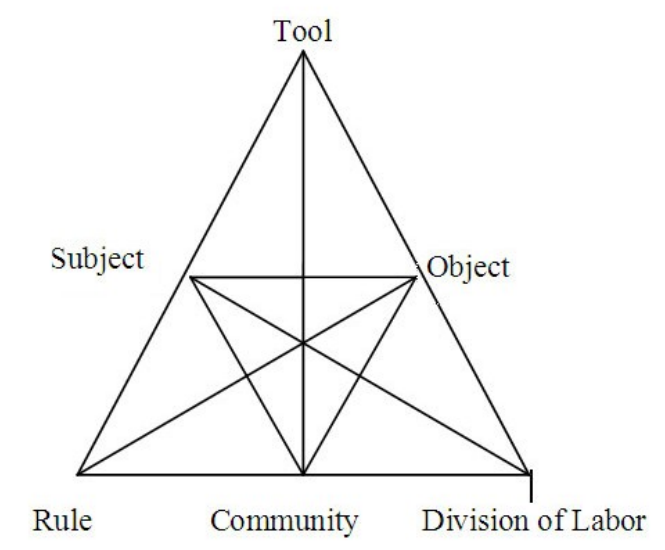

Figure 1: The model of an activity system

More specifically about the AT elements, Demiraslan and Usluel (2008) explain that,

The subject refers to the individual or group whose point of view is taken in the analysis of the activity. The object (or objective) is the target of the activity within the system. Tool refers to internal or external mediating artifacts which help to achieve the objective of the activity. The community is comprised of one or more people who share the objective with the subject. Rules refer to explicit and implicit regulations, norms and conventions that constrain actions and interactions within the activity system. The division of labor discusses how tasks are horizontally divided between community member (p. 459). 
Using the above model to analyze English teaching activity, the elements of AT of the present study can be mapped below:

\begin{tabular}{|c|c|c|}
\hline Subject & $\longrightarrow$ & $\begin{array}{l}\text { English teacher (teaching approach and } \\
\text { knowledge and skills related to English } \\
\text { language teaching (ELT). }\end{array}$ \\
\hline Object & & $\begin{array}{l}\text { The goals of ELT (quality communica- } \\
\text { tion skills both written and spoken). }\end{array}$ \\
\hline Tool & & Methods used for teaching. \\
\hline Rules & & Rules of the institution \\
\hline Community & & $\begin{array}{l}\text { Students, teachers, and institution's ad- } \\
\text { ministration }\end{array}$ \\
\hline ivision of Labor & & The roles and responsibilities of teachers. \\
\hline
\end{tabular}

In AT, contradictions are considered as its main characteristic or feature (Engestr?m, 1999). They are defined as "the misfit within elements, between them, between different activities, or between developmental phases of a single activity" (Kuutti, 1996:34). According to Kuutti (1996), contradictions can occur because there may be issues proposed by a certain party in a system that are against the principle of another party in the same system.

Despite the potential disruptions and conflicts they may cause (Murphy \& Rodruguez-Manzanares, 2008), particularly if not handled properly, contradictions are very significant because they are "the motive force of change and development" (Engestrom \& Miettinen, 1999:9). A dynamic system is the system which can take the benefits from the contradictions occurring in it (Engestr? $\mathrm{m}$, 2001). That is, the identified contradictions should be used as the means for the system to improve its activity (Engestrom, 1993). However, such an improvement can only be achieved if the work to resolve the contradictions is not taken at the individual level but is performed collaboratively (or at the collective level) between the members of the community (Murphy \& RodruguezManzanares, 2008). It is important to notice that the solution proposed by a certain member must be agreed and accepted by other members of the community (Engestr?m, 2001).

In this study, AT was used to examine the contradictions occurring in the English teaching activity at the classroom level. Therefore, the research question which guided the study was worded as follows: 
What are the contradictions within the English teaching activity in the case study institution?

\section{METHOD}

Four teachers undertaking full time teaching in a vocational higher institution in Indonesia were invited to take part voluntarily in this research. Prior to their recruitment, fliers containing information about the study, including researcher's contact details were sent to the potential teachers. As a result, five teachers contacted the researcher and expressed their interest to share their perceptions about their teaching. Nevertheless, owing to an urgent personal reason, one teacher withdrew his participation. So, in total there were four participants involved in this research and all of them were in charge of teaching English for Specific Purposes (ESP). Two teachers were responsible for teaching Business English and the other two taught English for Science. Although English was taught for use in specific content areas, the main emphasis of teaching was on the improvement of students' communication skill.

Semi-structured interview was chosen as the instrument for data collection. This tool was used because it allows the researcher to probe for views and opinions of the participants (Corbetta, 2003). Moreover, it gives the researcher the opportunity to gain deep information about the phenomena being investigated (Creswell, 2005). All the questions asked to the participants were intended to disclose all the issues which influenced their English language teaching. Particular attention was given to issues that were related to contradictions within the activity system (ELT).

Data were analyzed using NVivo 8 (2008). The tree nodes (thoughts and definitions about data, along with selected passages of text) were developed to create ideas, concepts, categories about the data. Walsh (2006) suggests that this computer software is very useful because it helps "organize raw data and links them with memos and 'databites' where researchers can make codes and analytical notes, and then edit and rework ideas as the project progresses" (p.353). As the data analysis was progressing, some important segments of narratives were identified and recorded to support the arguments regarding the contradictions occurring in the activity system. For preserving their anonymity, the participants were referred to as ET1, ET2, ET3, and ET4. 


\section{FINDINGS AND DISCUSSION}

The findings presented below were some of the contradictions (as indicated by lightning signs) which could be identified from the participants' responses.

It may result in a contradiction between the Subject and Tool (a) that the teachers are willing to promote the use of communicative approach in their teaching for helping learners improve their communication skill, but finds the textbooks provided are too technical in that they provide little room for them to develop communicative teaching. This is succinctly acknowledged in the following comment:

All the English teachers here are instructed to cover all the lessons in the textbooks supplied by the institution...These books in fact mostly contain definitions of technical or business related terms. (ET2)

The inadequacy of technical support staff results in a contradiction between Subject and Division of Labor (b) because teachers' effort to teaching English using computer technology such as internet and PowerPoint presentation is hampered by the lack of support from the technical staff. That is, these support staff are not around when the teachers need them most, particularly for dealing with the technical aspect of the technology. For example, during the interview, one teacher commented:

I like incorporating computer technology in my EFL teaching. For instance, I sometimes show learners about the real-life examples taken from the internet ... but lately I become frustrated with my technology mediated teaching owing to the technical problem that I experience with my computer. You know what...none of the technical support staff in this institution was available to help me when I had this problem. (ET 4)

The excessive workload assigned to teachers results in the teachers' inability to provide high quality teaching to learners. This condition has resulted in the contradiction between the Tool and Object (c). In fact, in order for teachers to provide quality teaching to learners, they need to be assigned a fine workload where there are opportunities for them to carry out a good preparation and participate in professional development activities for improving their professionalism (Dixon, Scott, \& Dixon, 2007). As one teacher said:

I am assigned too many teaching hours in this institution. Because of this, I hardly have time to do a good preparation for my teaching and improve my 
teaching skills. Rather than incorporating communicative teaching approach, I often ask learners to complete written exercises from the textbook. I do not really want to do this, but I just have to because I need to save my energy for other classes. (ET1)

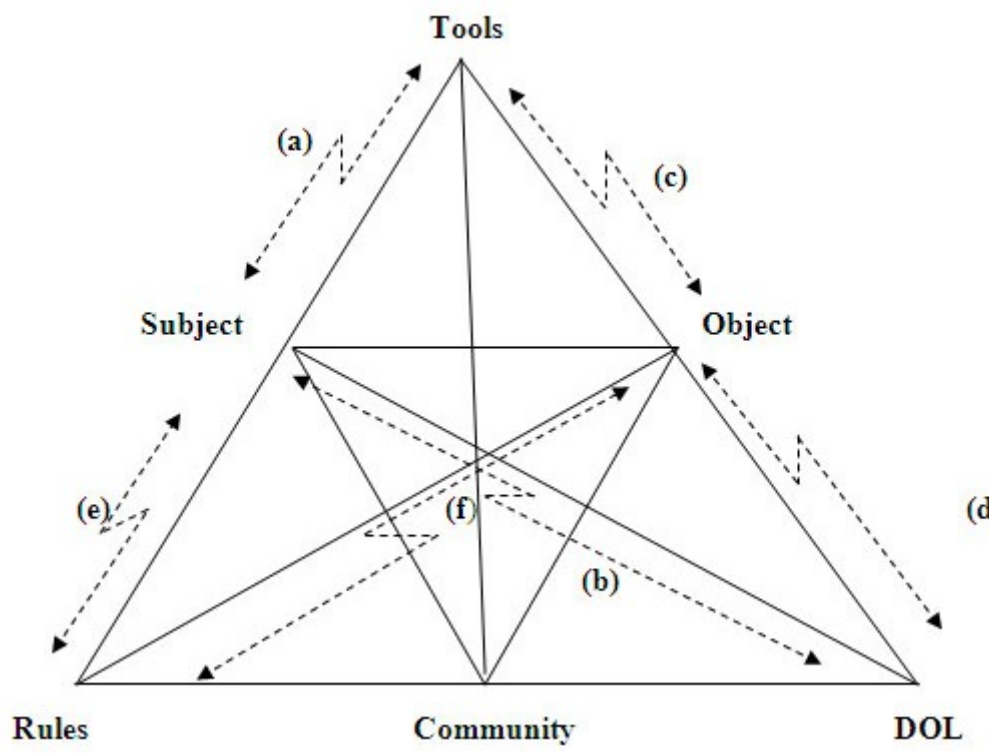

Figure 2: Contradictions within the activity system

The lack of coordination between the teachers and administrative staff (i.e. those in charge for the language laboratory management) results in the contradiction between Division of Labor and Object (d) because teachers' willingness to vary their teaching for improving learners' English communication competence using language lab is sometimes hampered by the unavailability of the room (used by other fellow teachers). As one teacher commented:

"I do not why I sometimes cannot use the language lab facility even though I have been scheduled to occupy it... Often as I and the students are heading to the lab, the room is being used by other teachers". (ET 3) 
A contradiction also occurs between the Subject and Rules (e) because teachers' willingness and efforts to create a communicative learning atmosphere is not supported by a number of institution's policies, including, among others those that are related to the teachers' workload (ET 1) and textbook use (ET 2). The policy associated with the improvement of teachers' teaching skills also brings about a contradiction between these two elements. During the interview, one teacher explained:

I have been working as a full time English teacher in this university for more than five years. But, as far as I remember, I only participated in two types of English teaching workshops: one on the use of technology for teaching and the other on curriculum development. Honestly speaking, the quantity of trainings I have received is far from adequate. So, I expect the institution can hold more training for English teachers. (ET 4)

The practices of the above rules may also prevent the achievement of English teaching objective, that is, to enhance learners' communication competence. In this sense, they bring about a contradiction between the Rules and Object (f).

\section{CONCLUSION AND SUGGESTIONS}

The success of English language teaching, ESP in particular, is influenced by various factors. To understand which factors may facilitate or constrain the ELT in an institution requires a good understanding of activity system in which they are situated. An analysis of contradictions using activity theory (AT) is one of the ways which can be adopted by the researcher to obtain this understanding (Engestr?m, 2001). Through such analysis approach, not only can he or she gain an understanding about the processes within the activity system, ELT in this sense, but also she or he can identify problems that need to be addressed for improving the system. In this article, I adopted AT for analyzing the contradictions occurring within the activity system. The contradictions herein are not seen merely as the problems, but they are regarded as the useful sources for improvement (Nelson, 2002).

This study observed a number of contradictions within the context of ELT in the case study institution. First, the use of compulsory ESP textbook has in fact constrained teachers in their efforts to help learners to develop their English communication competence. This is partly due to the fact that the contents 
of the book (mostly about definitions of terms) do not provide enough rooms for teachers to develop their communicative teaching. The policy requiring teachers to only use this book for teaching should be reviewed and it is highly recommended that the policy which allows teachers to incorporate other materials including those obtained from internet can be generated. There are a lot of good and authentic teaching materials which can be accessed from the website. It is important to be noted that English learning should be made as fun as possible to enable learners speed up their English mastery and one way of doing it is by presenting them with interesting teaching materials and avoiding the use of poor quality materials.

Second, the contradiction due to the inadequacy of technical support staff for supporting teachers in their use of computer technology should not happen again in the future. For this purpose, assessment should be carried out to ensure that there is an adequate number of technical staff who can provide quality support for teachers in their technology assisted English teaching. Problems associated with the mismanagement of language laboratory, as the third contradiction identified in this study, can be solved by improving the quality of teachers and administrative staff coordination. Written agreement between them, if possible, can be passed on to each one of them as the guide for their action. In this way, they (teachers and administrative) can remind the teachers who are using the lab facility outside their scheduled time.

The contradiction triggered by teachers' lack of professional development can be alleviated by undertaking careful assessments, such as the assessment of the kinds of development activities that teachers need at most and the cost for holding the activities. Most importantly, all the teachers will have the opportunity to improve their English teaching knowledge and skills.

Finally, this study has provided some recommendations for the improvement of ELT in the case study institution. Such recommendations are made based on the findings regarding the contradictions happening within the system (ELT) using activity theory (AT) as the framework. This study, however, has some limitations. The main limitation is that it involved a small number of teachers and therefore the results obtained might not be generalizable. In this sense, further study involving a larger sample of teachers is a necessity. Since this study only addressed the issue of contradictions within the context of ELT in a vocational higher institution, further research can also be conducted within the different levels of education such as primary or secondary schools. 


\section{REFERENCES}

Corbetta, P. 2003. Social Research Theory, Methods and Techniques. London: SAGE Publications.

Creswell, J. W. 2005. Educational research : Planning, Conducting, and Evaluating Quantitative And Qualitative Research (2nd ed.). Upper Saddle River, N.J.: Pearson Education.

Demiraslan, Y., \& Usluel, Y. K. 2008. ICT integration processes in Turkish schools: Using activity theory to study issues and contradictions. Australasian Journal of Educational Technology, 24(4):458-474.

Dixon, K., Scott, S., \& Dixon, R. 2007. The Impact of Increasing Workload on Academics: Is There Time for Quality Teaching. Paper presented at the AARE International Educational Research Conference, Fremantle. .

Engestrom, Y. 1993. Developmental Studies of Work as a Testbench of Activity Theory: The Case of Primary Care Medical Practice. In S. Chaiklin \& J. Lave (Eds.). Understanding practice: Perspectives on Activity and Context (Pp. 64-103). Cambridge: Cambridge University Press.

Engestr?m, Y. 2001. Expansive Learning at Work: Toward an Activity Theoretical Reconceptualization. Journal of Education and Work, 14(1):133156.

Engestrom, Y., \& Miettinen, R. 1999. Activity Theory and Individual and Social Transformation. In Y. Engestrom, R. Miettinen \& R. L. Punamaki (Eds.), Perspectives on Activity Theory, pp. 19-38. Cambridge: Cambridge University Press.

Kuutti, K. 1996. Activity Theory as a Potential Framework for Human Computer Interaction Research. In B. A. Nardi (Ed.), Context and Consciousness. Cambridge, MA: MIT Press.

Lim, C. P., \& Hang, D. 2003. An Activity Theory Approach to Research of ICT Integration in Singapore Schools. Computers \& Education, 41:49-63.

Murphy, E., \& Rodruguez-Manzanares, M. A. 2008. Using Activity Theory and Its Principle of Contradictions to Guide Research in Educational Technology. Australasian Journal of Educational Technology, 24(4):442457. 
Murphy, P. 2007. Organisational Learning \& ICT Integration Strategies in Higher Education Institutions. Paper presented at the World Conference on E-Learning in Corporate, Government, Healthcare, and Higher Education 2007, Quebec City, Canada.

Nelson, C. 2002. Contradictions in Learning to Write in a Second Language Classroom: Insights from Radical Constructivism, Activity Theory, and Complexity Theory. The University of Texas.

NVivo8.0. 2008. Qualitative Data Analysis Computer Software. Doncaster, Victoria: QSR International Pty Ltd.

Robertson, I. 2008. Sustainable E-learning, Activity Theory and Professional Development. Paper Presented at the Ascilite Conference, 30 November 3 December, Melbourne. .

Walsh, M. 2006. Teaching Qualitative Analysis Using QSR NVivo. The Qualitative Report, 8(2):251-256. 